\title{
Between Codification and Legislation: a Role for the International Law Commission as an Autonomous Law-Maker
}

\author{
Yifeng Chen
}

\section{Introduction}

The United Nations International Law Commission, an institution entrusted with the responsibility to codify and progressively develop international law, ${ }^{1}$ continues to play a pivotal role in the international legal process. Challenges and doubts notwithstanding, ${ }^{2}$ the Commission has proved itself as a pertinent contributor to the international law-making process over the course of the past seventy years.

The past decade has witnessed the reinvigoration of the International Law Commission, both institutionally and intellectually. In terms of its legislative functions, the Commission has been actively expanding its working territory. The Commission has not only continued to address traditional topics primarily in public international law, in accordance with paragraph 2 of article 1 of its statute, ${ }^{3}$ such as customary international law, the law of treaties, and jus cogens, but also started considering more specialized fields of international law, as seen in the agenda items "Protection of atmosphere", "Protection of the environment in relation to armed conflicts", "Crimes against humanity" and others. ${ }^{4}$ The International Law Commission is imbued with a renewed confidence to take up topics "that reflect new developments in international law and pressing concerns of the international community as a whole". 5

The intellectual reinvigoration of the Commission has also led to the diversity in the forms of the final products of the Commission. The Commission

1 Statute of the Institute of International Law (adopted 1o September 1873) article 1.

2 Doubts were once raised about the continual relevance of the International Law Commission. See Christian Tomuschat, "The International Law Commission - An Outdated Institution?' (2006) 49 GYIL 77-105.

3 Statute (n 1$)$ article 1 (2).

4 See UN Doc A/CN.4/709/Rev.1 and UN Doc A/CN.4/723.

5 See ILC, 'Report of the International Law Commission on the work of its forty-ninth session' [1997] II(2) ILC Ybk 1, para 238. 
has produced not only conventions and draft articles, but also declarations, model rules, draft codes, draft statutes, guiding principles, draft principles, conclusions, guides to practice and draft guidelines. The Commission has shown much flexibility in adopting different forms for its work. It is evident from those designations that some topics were not conceived as necessary or desirable for further development into conventions. This diversity in form raised the issue of practical usefulness and, theoretically, the legitimacy of this type of work. ${ }^{6}$

This brings to the forefront of debate the role of the Commission in international law-making. This article argues that both the notion of "codification" and the positivistic concept of international law, which have for long determined the Commission's working methods and self-identity, require critical re-examination. The contribution of the Commission to the development of international law should not be solely measured by reference to its ability to produce conventions. It is also desirable to investigate the multiple roles that the Commission has played in the broad international law-making process.

In light of the expanding reach of the Commission's work, the diversity of form in its work products, and its increasing impact, this article aims to critically assess the role the International Commission played in the development of international law over the past seven decades. While Part II traces the historical emergence of the Commission's mandate back to the second half of the 19th century, it argues that "codification of international law" has been constructed as a political project for international peace. In Part III, this concept of codification is examined from the point of view of a spectrum, where two approaches, "registering" and "legislative", are placed at its ends. The article asserts that competing conceptions of codification have not only been determinative of the work of the Committee of Experts for the Progressive Codification of International Law, but are also affecting the institutional role that the International Law Commission plays today. This amalgam of registering and legislative approaches, evident in the Commission's dual mandate for "promotion of the progressive development of international law and its codification", has provided room for flexibility for the Commission to adapt to the changing landscape of international law. In light of the historical analysis of the Commission's mandate, Part IV focuses on the practice of the Commission today, and critically assesses the Commission's work in respect to their diversity of

6 See Sean D Murphy, 'Codification, Progressive Development, or Scholarly Analysis? The Art of Packaging the ILC's Work Product' in Maurizio Ragazzi (ed), The Responsibility of International Organizations: Essays in Memory of Sir Ian Brownlie (Martinus Nijhoff 2013) 29-40. 
form and sources of authority. The article concludes by a theoretical account of the future of the Commission, as an institution becoming an autonomous law-maker in international law.

\section{Situating the Codification Project Historically}

The idea of codifying international law has its intellectual roots in the pioneer works of Jeremy Bentham, who not only coined the term international law, but also advocated for an international code. The codification project started to take its shape in the second half of the 19thcentury, first through personal engagement by individual international lawyers, including Johan Caspar Bluntschli and David Dudley Field, and later continued to develop through collective efforts of private associations of international lawyers. ${ }^{7}$ While the Hague Conferences of 1899 and 1907 have often been characterized as being instrumental for the codification of international law, ${ }^{8}$ conscious and sustained efforts of codification at inter-governmental level, however, only started in the 1920 under the auspices of the League of Nations. ${ }^{9} \mathrm{~A}$ critical step towards institutionalized codification was the establishment of the International Law Commission, by General Assembly resolution 174(II) of 21 November 1947, a permanent institution of experts entrusted with a general competence to codify and progressively develop international law.

Several observations can be made on the evolution of codification as a historical project. First of all, codification of international law as a professional aspiration was deeply internalized in the international legal profession from its very beginning in the late 19th century. The Institute of International Law, established in 1873 by eminent European-American jurists, was preoccupied with the codification of international law. The statute of the Institute of International Law states expressly that "its purpose is to promote the progress of international law", among other means, "by lending its co-operation in any serious endeavour for the gradual and progressive codification of international law". ${ }^{10}$ Indeed several distinguished members of the Institute served in the

7 For an overview of various private efforts at codification, see Ramaa P Dhokalia, The Codification of Public International Law (Manchester University Press 1970) 37-75.

8 See Arthur Watts, 'Codification and Progressive Development of International Law' Max Planck Encyclopedia of Public International Law (December 2006) <opil.ouplaw.com/ home/EPIL >.

9 See Shabtai Rosenne, 'The International Law Commission 1949-1959' (1960) 36 BYIL 104, 107-109.

10 Statute of the Institute of International Law (adopted 10 September 1873) article 1. 
League of Nations Committee of Experts on the Progressive Development of International Law, or later played an active role in the Codification Conference of 1930. ${ }^{11}$ The Association for the Reform and Codification of the International Law (later renamed as the International Law Association) established in 1873, with its origin in the American peace movement, was equally committed to furthering the codification of international law alongside its project advocating the institutionalizing a world court. ${ }^{12}$ Codification was a professional vision shared among elite European and American international lawyers, seen as an instrument for the progress of international law, and as a political project for international peace. The project of codification embodied the liberal ideas of progress, reason and humanity. ${ }^{13}$ Codification is also a constitutive element of an international society in the sense that it "presupposes for the society concerned a sufficient basis of common experience and conviction to ground effective rules regulating the group's future social relationship".14

Secondly, the codification of international law was closely associated with the emergence of international courts and tribunals. The development and relative success of arbitration as of the late 18 th century had prompted much hope for establishing a permanent judicial body to settle disputes among States. For instance, the peaceful settlement of the Alabama case through arbitration in 1872 was perceived as an encouraging development by international lawyers and pacifists. Establishment of a world court and codification of international law become twin projects advocated by the international peace movement of late 19th century. Codification of international law became more pressing with the world's growing faith in international dispute settlement mechanisms by the turning of the 2oth century. In this regard, a code of international law was expected to help clarify the mutual rights and obligations of States: and avoid disputes. "Codification is plainly of the greatest value for assuring certainty and clearness in the law. These advantages ... are especially valuable in the

\footnotetext{
11 For example, Hjalmar Hammarskjöld, who contributed remarkably to the work of the Committee of Experts for the Progressive Codification of International Law as its chair, was a member and president (1928) of the Institute of International Law.

12 For the early codification project in the United States, see Mark Weston Janis, The American Tradition of International Law: Great Expectations 1789-1914 (Clarendon Press 2004) 117-133.

13 See Martti Koskenniemi, 'International Legislation Today: Limits and Possibilities' (2005) 23 WILJ 61, 65-68.

14 Julius Stone, 'On the Vocation of the International Law Commission'(1957) 57 ColumLRev 16 , 33. The constitutive role that codification plays in international society is also emphasized by Shabtai Rosenne, 'Codification Revisited after 5 o Years' (1998) 2 MaxPlanckUNYB 1.
} 
case of international law."15 Especially with the establishment of the League of Nations and of the Permanent Court of International Justice, States possessed much optimism and enthusiasm for the codification of international law. It was felt that the gradual restatement of international law into more precise written form had "become still more necessary since the creation of the Permanent Court of International Justice". ${ }^{16}$ To tie the codification of international law to international dispute settlement produced a profound effect on our understanding of international law as a body of rules for the peaceful resolution of disputes between States.

Thirdly, the codification of international law was conceived as an instrument for social reform and progress. In the absence of a centralized legislature at the international level, the exercise of codification was largely appreciated as a substitutive form of international legislation. In the words of the former American Sectary of State Elihu Root, "what is called for now and what we mean when we speak of codification of international law is the making of law."17 A similar view was held by Robert Jennings that "codification properly conceived is itself a method for the progressive development of the law".18

The codification project in the early 2oth century was a continuation of the peace conferences of 1899 and 1907 in the sense that the object of the project was to produce a systemized body of rules for international relations. ${ }^{19}$ However, it was also well understood that codification would offer a novel way, different from that of a diplomatic conference, to advance international law and

15 Speech addressed by Mr. Hjalmar Hammarskjöld, Chair of the Committee of Experts for the Progressive Codification of International Law, in the first session of the Committee on 1 April 1925, see Shabtai Rosenne (ed), League of Nations Committee of Experts for the Progressive Codification of International Law (1925-1928) (Oceana 1975) Volume I (Minutes) 3 .

16 Ibid 5 .

17 Elihu Root, 'Codification of International Law' (1925) 19 AJIL 675, 681.

18 Robert YJennings, 'The Progressive Development of International Law and its Codification' (1947) 24 BYIL 301, 302.

19 In a memorandum entitled 'A Historical Survey of the Development of International Law and its Codification by International Conferences', submitted by the United Nations Secretariat to the Committee of Experts for the Progressive Codification of International Law, the codification of international law was traced back to international conferences of mid-19th century. It was noted that "the development of written international law through the restatement of principles of existing law or through the formulation of new law (these two methods being frequently undistinguishable), was pursued at over 100 international conferences or congresses held between 1864 and 1914, resulting in over 250 international instruments." United Nations Secretariat, 'A Historical Survey of the Development of International Law and its Codification by International Conferences' (29 April 1947) UN Doc A/AC.10/5, reprinted in (1947) 41 AJIL Supp 29, 32. 
peace. Codification had been seen as a soft means of formulating international legislation. Compared to legislation in diplomatic conferences, the method of codification was welcomed as an exercise that was undertaken by experts and deeply rooted in reason and human conscience. It was also commended for its scientific nature. Of course, codification also indicated a gradual and limited diversion of powers from rulers of States to experts in international law. However, the tension between codification and legislation has never been properly settled. The uncertainty about the very nature of codification is in constant debate and still has an impact on the work of the International Law Commission today.

As the idea of codification emerged as a historical project of a specific time, the codification project carries with it a specific intellectual and ideological outlook on international law. First of all, the idea of codification is built upon a rule-based, formalistic notion of international law. ${ }^{20}$ Rules are objective and their meanings ascertainable. It keeps a distance from both morality and politics. Secondly, it assumes a scientific approach to international law. ${ }^{21}$ International law is perceived as a discipline of science, based on rationality, logic and structure, and amenable to systemization and organization. The justification of codification rests upon the scientific nature of the discipline of international law. Thirdly, it is developed by a faith in international law as an organic system, in subjecting the totality of international relations to the rule of law. ${ }^{22}$ The idea of international law as an organic system implies the completeness of international law as well as its dynamics. It is a progressive and structured notion of international law. It is observed that the International Law Commission is pre-eminently guided by, among other general principles, "its faith in the potential of international law for achieving international peace, security and justice". ${ }^{23}$ Fourthly, as with other projects of international law, the codification project embeds a State-centered, positivistic perspective to international law. Exactly because of its inherently legislative nature, any credible codification project would require sovereign endorsement in one way or another. The success of the International Law Commission is often attributed to its healthy

20 Martti Koskenniemi refers to "the culture of formalism", see Martti Koskenniemi, The Gentle Civilizer of Nations: The Rise and Fall of International Law 1870-1960 (CuP 2001) 500-509.

21 For a critical examination on international law as a science, see Anne Orford, 'Scientific Reason and the Discipline of International Law' (2014) 25 EJIL 369.

22 For a seminal work in this regard, see Hersch Lauterpacht, The Function of Law in the International Community (Clarendon Press 1933).

23 Bertrand G Ramcharan, The International Law Commission: its Approach to the Codification and Progressive Development of International Law (Martinus Nijhoff 1977) 164. 
interaction with governments, for example, through the Sixth Committee of the General Assembly.

\section{The Concept of Codification Revisited}

While the notion of codification in international law borrows from domestic analogies, the very nature and boundary of codification is much disputed in international legal scholarship as well as in practice. The issue is not simply of a theoretical interest. Rather, as international practice has illustrated, the choice of an institutional philosophy for codification profoundly defines and constrains the actual work of that codification institution. This is because competing ideas of codification carry with them varying implications for their nature, working methods, and limitations. ${ }^{24}$ At times, the tension between various notions of codification may even frustrate the work of the codification institution. The success or failure of the codification endeavors can hinge upon the ability of the codifier to develop an appropriate institutional approach to codification. $^{25}$

\section{$1 \quad$ Competing Conceptions of Codification}

In international law scholarship and practice no single, generally accepted conception of codification exists. Many competing and even contradicting notions of codification can be found. ${ }^{26}$ On the one end of the spectrum is a "registering approach" that refers to codification as a scientific registration of unwritten international law. Here, codification is more concerned with the

24 The observation by Yuen-Li Liang in 1947 is an illustrative example. "The very fact that codification always involves certain legislative processes, aside from the process of consolidation, has resulted in a paradox as to method. While the work of consolidation is generally admitted to be a scientific task which can best be done by professional lawyers, rather than by governmental representatives, the legislative processes require the consent of governments." See Yuen-Li Liang, 'The Progressive Development of International Law and its Codification under the United Nations' (1947) 41 ASILPROC 24, 33 .

25 The failure of the Codification Conference during the League of Nations is attributable to, among others, the lack of a common understanding of codification to guide through its work. See Dhokalia (n 7) 129-131.

26 See, for example, Liang (n 24) 32; James Brierly, 'Codification of International Law' (1948) 47 MichLRev 2; also Alain Pellet, 'Responding to New Needs through Codification and Progressive Development' in Vera Gowlland-Debbas (ed), Multilateral Treaty-Making: The Current Status of Challenges to and Reforms Needed in International Legislative Process (Kluwer 2000) 13-23. 
systemization of law, aiming at the systematic statement of the law in written form. Its application is retrospective, therefore one has to wait until a topic is ripe for codification. Under this approach, codification should mainly deal with the identification, consolidation and elaboration of existing laws. The ripeness of a topic is measured primarily by the abundance of agreed rules on the topic. Progressive development of law is discouraged in the codification process, if not completely avoided. While room for creativity in codification is acknowledged, it is often understood as an exception or unavoidability, and, in any case, marginal. ${ }^{27}$ The output of such codification can take form of a codelike restatement and does not need to be sent for State ratification. The Declaration concerning the Laws of Naval War adopted by principal naval powers during that time on 26 February 1909 is an illustrative example. ${ }^{28}$ The value and authority of the statement would depend on the merit of the work itself. ${ }^{29}$ As the very idea of codification is to restate existing law, to present it in the form of a draft treaty and ask for State ratifications might only be detrimental to the codification exercise, as States may refuse to ratify, or make reservations to, treaties. ${ }^{30}$ Under the registering approach, codification is a scientific exercise, which is better entrusted to a group of legal experts. If codification is essentially scientific in nature and the work is to be judged by its quality, private codifications by individuals or associations such as Institute of International Law are also of great importance.

At the other end of the spectrum, however, lies a "legislative approach" which perceives codification in terms of international legislation, a political exercise of legislative power pursued by States collectively, usually through diplomatic conferences. There, codification is not constrained by existing laws. It is seen as a technique for the progress of international law, ${ }^{31}$ and encompasses

27 This is the understanding of codification usually among English lawyers, see Brierly (n 26) 2.

28 See United Nations Secretariat (n 19) 43-49.

29 See United Nations Secretariat, 'Methods for Encouraging the Progressive Development of International Law and its Eventual Codification', A/AC.1o/7 (6 May 1947), reprinted in (1947) 41 AJIL Supp 111, 116. The same opinion was advocated by Professor James Brierly at the Committee on the Progressive Development of International Law and its Codification when drafting the statute of the International Law Commission, see 'Summary Record of the 2nd Meeting' (13 May 1947) A/AC.10/SR.2, 5.

30 For an account of the limits of using international treaties to codify customary international law, see Jennings (n 18).

31 The memorandum written by Hersch Lauterpacht actively advocated a liberal and progressive interpretation of codification, see ILC, 'Survey of International Law in Relation to the Work of Codification of the International Law Commission: Preparatory work within the purview of article 18, paragraph 1, of the of the International Law 
law-making activities including both the restatement of existing laws and the development of new laws. It may revise old law when needed, and may also formulate new law in novel fields where few written rules exist. Codification is then a forward-looking exercise and should address the pressing needs of international society. The criterion for the selection of topics for codification is determined by the needs of international society and the boundaries of the work are marked by the political will of States. In other words, in deciding whether a topic is ripe for codification, ripeness is assessed not by reference to abundance/scarcity of existing rules on the topic, but by a careful evaluation of the acceptability of the proposed rules to States. From the perspective of the "legislative approach", codification is an unavoidable political exercise, and for this reason, should involve State representatives in the process. Therefore, draft conventions are considered to be the only proper form of codification. The codified texts are subject to further scrutiny and acceptance of States. The codification process is completed with the convocation of diplomatic conferences and the formal adoption of conventions. Under this legislative approach, the authority of the codified texts derives from the consent of States.

Although the two approaches at the end of the spectrum are in a way exaggerated and overly simplified, they are nevertheless useful to highlight the divergent views of codification in international law. A purely registering or legislative approach is only possible as a theoretical construction. In reality, when the task of codification is institutionalized, the codification institution often embarks on a middle road, as the examples of the League of Nations Committee of Experts for the Progressive Codification of International Law and the International Law Commission have shown. ${ }^{32}$ Both of these bodies have exhibited a great extent of flexibility in absorbing elements of both approaches.

\section{$2 \quad$ Experience of the Committee of Experts for the Progressive Codification of International Law}

At the initiative of the Swedish Government, the League of Nations established the Committee of Experts for the Progressive Codification of International Law (hereafter "Committee") in 1924, with the mandate to identify the subjects of international law which were "desirable and realisable" for codification. ${ }^{33}$ The

Commission - Memorandum submitted by the Secretary-General' (10 February 1949) UN Doc A/CN.4/1/Rev.1.

32 For an excellent exposition of the actual work of codification at the International Law Commission in its formative period of time, see Hersch Lauterpacht, 'Codification and Development of International Law' (1955) 49 AJIL 16.

33 League of Nations, 'Resolution adopted by the League of Nations Assembly on 22 September 1924' (1924) League of Nations Official Journal Spec Supp 21, 10. 
Committee, consisting of 17 members representing "the main forms of civilisation and the principal legal systems of the world", ${ }^{34}$ comprised judges from the Permanent Court of International Justice, governmental legal advisors, professors, diplomats and practitioners. From 1925 to 1928, the Committee convened for four sessions, where it deliberated on appropriate approaches and possible topics for codification. This was the first time that codification of international law had been officially undertaken under the auspices of an international organization. Although the actual outcomes of the codification efforts are often greeted with regret, the institutional experience gained during the League of Nations Committee remains highly relevant.

Central to the debates of the Committee, among other issues, were the notion of "codification" and its implications for the scope, methodology and procedures of the work of the Committee. Even before the Committee embarked upon its work, its chairperson, the Swedish member Mr. Hjalmar Hammarskjöld circulated an advance working paper and brought up the nature of codification. He asked: "Are we simply asked to give methodological form and arrangement of rules which already exist, at the most, to reduce to writing ideas on which there is universal agreement? Or are we to go further, and to consider how far innovations are desirable or possible and how far resolutions may be found for questions which are still subject to controversy?"35 The Committee devoted its first five meetings elaborating the idea of codification in international law and its implications for the Committee's mandate.

During the debates, two different conceptions of codification emerged. The two positions were nicely summarized by the Chinese member Wang Chung-Hui, Deputy-Judge at the Permanent Court of International Justice at that time ${ }^{36}$ who stated that "[c] odification in a narrow sense might be taken

34 The members of the Committee of Experts were not elected by the Council or the Assembly on an individual basis, were approved as a whole by the Council at the recommendation of Sweden. The composition of the Committee is dominantly European. The Committee was composed by Hjalmar Hammarskjöld (Sweden) (Chairman), G. Diena (Italy) (Vice-Chairman), M. C. Botella (Spain), James Brierly (United Kingdom), M. Fromageot (France), J. Gustavo Guerrero (Salvador), Bernard Cornelis Johannes Loder (Netherlands), Barbosa De Magalhaes (Portugal), Adalbert Mastny (Czechoslovakia), M. M. Matsuda (Japan), Szymon Rundstein (Poland), Walther Schücking (Germany), José León Suarez (Argentine), Charles de Visscher (Belgium), Wang Chung-Hui (China), and George W. Wickersham (United States of America).

35 UN Doc C. P. D. I/2, 6 March 1925, in Rosenne (n 15) xxxvii.

36 Wang Chung-Hui [王宠惠] (1881-1958) was the first law graduate from a modern Chinese university (Beiyang University, Tianjin, 19oo). Dr. Wang had a prominent political career in Republican China, holding important positions, for example, the Minister of Foreign Affairs and Prime Minister at the Peking Government and the Minister of Justice 
to mean simply a restatement of existing law, a reduction to writing of what was already accepted and acted upon in practice" and that "codification in the broader sense involved proposals for the alteration of existing rules, either by modifications or additions". ${ }^{37}$ The majority of the Committee, including its chairperson, was in favour of a progressive idea of codification. For Hammarskjöld, "the duty, therefore, of the Committee was not merely to codify in the strict or Anglo-Saxon sense of the word", he added that "it could make proposals with a view to codifying, amending and completing international law".38 Similar ideas were expressed by other members who shared an optimistic outlook on codification. ${ }^{39}$ These members were ambitious about codification projects and were keen to promote peace through international law. Codification was seen as a tool for social progress. In the view of Suarez, for example, "the task of the Committee was not merely passive and confined to codifying points on which the States seemed to be in agreement ... The Committee had also an active mission in the sense of drawing attention to general principles and seeking general conclusions, and of steeling questions in regard to which the modern international community of interests made it necessary to secure legal uniformity."40 While codification did not aim to produce a code of international law, it should respond to the legislative needs of international society.

To the contrary, some other members stick to a conservative approach to codification through a pragmatic reading of the Committee's mandate. ${ }^{41}$ In the view of Professor de Visscher and Professor Brierly, the Committee was only instructed to "prepare a provisional list of the subjects of international law" capable of being developed into international agreements. Professor de Visscher stated that: "the Committee must aim at encouraging the conclusion of new conventions between States ... The essential object was to discover, in a concrete and practical form, what was acceptable to the Governments." ${ }^{22}$ For him, the theoretical debates on the difference between codification and legislation "would lead to no result". ${ }^{43}$ In any case, the Committee should not enter into

and Minister of Foreign Affairs at the Nanjing Government. Internationally, he served as deputy judge and then judge at the Permanent Court of International Justice (1922-1936). Dr. Wang was also a member of the Chinese delegation to the United Nations Conference in San Francisco in 1945 .

37 Rosenne (n 15) 21.

38 Ibid 11 (Hammarskjöld).

39 Ibid 6-7 (Suarez), 7-8 (Diena), 10 (Schücking), 12-13 (Rundstein), 20-21 (Wang).

40 Ibid 6 (Suarez).

41 See, for example, ibid 9-10, 24-25 (de Visscher), 15-16 (Brierly).

42 Ibid 24 (de Visscher).

43 Ibid 9 (de Visscher). 
the sphere of international legislation, a reserved prerogative for sovereigns only. As emphasized by the French member Mr. Fromageot, State consent, "either registered by means of conventions or tacit [sic]", was as the only existing basis of international law. ${ }^{44}$

The lengthy debate in the Committee did not lead to any definitive or generally accepted concept of codification. No general agreement emerged in the Committee as to the very nature of codification. The tension between the "legislative" and "registering" conceptions was recognized by the Committee. As Professor de Visscher observed, "[q]uoting the terms of the Assembly resolution, it might be said that codification in the strict sense appeared to be the most realisable task, and in the broader sense the most desirable." 45 This foreran the debate on the criterion of ripeness for codification in the context of the International Law Commission. Meanwhile, the dynamic and mixed nature of codification was also appreciated by the Committee. As de Visscher stated, "codification, even in the strictest sense, always implied a certain legislative element". 46

Having agreed on the disagreement, the Committee then proceeded with its work without settling on a concept of codification. The ongoing state of unsettlement left the Committee and its members with little guidance on the actual performance of their task. Some sub-committees concluded their reports with "draft conventions", "draft provisions" or "conclusions", and some not even conclusions. ${ }^{47}$ The diversity of the reports produced by various sub-committees was in a way reflective of different interpretations among members on the nature of codification and the expected output from various sub-committees.

The vagueness associated with the term "codification" was also to a certain extent accountable for the failure of the eventual Codification Conference of 1930. States came with divergent expectations on the objectives of the conference, whether it be for registration or legislation. ${ }^{48} \mathrm{~A}$ predominantly registering notion of codification underlying the preparation of the conference encountered a legislative experience in the actual codification exercise. The differences between States were often revealed only in the course of codification. This left the States with a negative perception that the conference was underprepared and disorganized. ${ }^{49}$

\footnotetext{
44 Ibid 16 (Fromageot).

45 Ibid 24 (de Visscher).

46 Rosenne (n 15) 24 (de Visscher).

47 Ibid lviii.

48 See United Nations Secretariat (n 19) 87-9o.

49 Dhokalia (n 7) 126-133.
} 
The Statute of the International Law Commission: Distinguishing Codification from Progressive Development

Article 13 of the Charter of the United Nations on the codification of international law had its origin in a proposal of the Chinese government to the Dumbarton Oaks Conference in its second phase, suggesting that "the General Assembly should be responsible for initiating studies and make recommendation with regard to the development and revision of rules and principles of international law".$^{50}$ China, who had experienced the injustice of unequal treaties and the impotence of the League of Nations, placed high hopes on international law and the future, which the United Nations could bring about for a just world order. At the Committee II/2 of the San Francesco Conference, lengthy discussion took place on the notions of "codification", "development" and "revision". "Revision" was eventually removed from the text, partly on the suggestions of some States that "development" could comprise "revision". ${ }^{51}$ In the final formula, the General Assembly would encourage "the progressive development of international law and its codification".

The Committee on the Progressive Development of International Law and its Codification, which was entrusted with drafting the statute of the International Law Commission, again had heatedly debated on the concept of codification and the role of the Commission. ${ }^{52}$ On the one hand, Professor James Brierly, the representative of the United Kingdom, proposed a scientific approach to codification. In his view, "[c]odification was a scientific and not a political task", and the work should be entrusted to "a small group of personal experts". ${ }^{53}$ The codification institution should "not concern itself with the substance of international legislation", as "the task of selecting topics was for political representatives not for lawyers". ${ }^{44}$ On the other hand, Professor Vladimir Koretsky from the then Union of Soviet Socialist Republics advocated for a political approach to codification. For him, an international convention was the only proper form of codification, as codification would necessarily involve

$5^{\circ}$ Chinese Proposal on the Dumbarton Oaks proposals: 'Dumbarton Oaks Proposals' Washington Conversations on International Peace and Security Organization (Washington DC 21 August - 7 October 1944) in Documents of the United Nations Conference on International Organization, Volume 3, Doc 1, G/1 (a) (1 May 1945) 25.

51 See Liang (n 24) 29-30; also Rosenne (n 9) 109-110.

$5^{2}$ For a useful summary of the discussion at the Committee, see Yuen-Li Liang, 'The General Assembly and the Progressive Development and Codification of International Law' (1948) 42 AJIL 66, 69-77.

53 For the opinions of Professor James Brierly, see 'Summary Record of the 2nd Meeting' (13 May 1947) UN Doc A/AC.10/SR.2, 5 .

Ibid. 
the creation of laws. He further considered that the United Nations "is an intergovernmental agency and not a superstate" and "could not oblige the states to accept norms". The task of codification was better entrusted to governmental representatives. ${ }^{55}$ The form of international convention should apply to progressive development as well as the restatement of international law.

It was during the drafting process of the statute of the International Law Commission that the normative distinction between codification and progressive development was consolidated, in consequence of which the term codification started to receive a technical connotation. In a memorandum prepared by the Secretariat of the United Nations, a distinction was drawn as to the method of codification between international convention and restatement. ${ }^{56}$ The United States also formally proposed a clear distinction between "progressive development" and "codification".57 With codification being "the scientific restatement of existing rules and principles of international law",58 progressive development meant, in the words of Professor Philip Jessup, "development of new law to meet the world's needs".59 While both concepts should fall within the working scope of the International Law Commission, the methods and procedures for the two different types of work necessarily varied. The proposed distinction between codification and progressive development was well received among the members, ${ }^{60}$ although it was also generally felt that an absolute distinction was impossible to retain in reality. ${ }^{61}$

55 For the opinions of Professor Vladimir Koretsky, see Committee on the Progressive Development of International Law and its Codification, 'Summary Record of the 4th Meeting' (15 May 1947) UN Doc A/AC.10/SR.4, 4-7; 'Summary Record of the 9th Meeting' (22 May 1947) UN Doc A/AC.10/SR.9, 13-15.

56 United Nations Secretariat (n 29) 111-116.

57 See 'Suggestions by the United States' (12 May 1947) UN Doc A/AC.10/14; also printed in United States Department of State Bulletin (1947) Vol 16, 1029-103o.

58 See ibid.

59 'Statement by the United States Representative on that Committee, Philip C. Jessup' in United States Department of State Bulletin (1947) Vol 16, 1026-1029.

6o During the discussion, this view is generally shared by members like Professor James L. Brierly (United Kingdom), Dr Alexander Eudzinski (Poland), Dr Enrique Ferrer Vieyra (Argentina), Dr J. G. de Beus (Netherlands), Professor Henri Donnedieu de Vabres (France). An opposite opinion was however held by Professor Vladimir Koretsky, see 'Summary Record of the 4th Meeting' (15 May 1947) UN Doc A/AC.10/SR.4, 5.

61 For example, the Chinese representative Dr Shuhsi Hsu (China) considered codification to be part of the development of international law, see 'Summary Record of the 3 rd Meeting' (14 May 1947) UN Doc A/AC.10/SR.3, 5. Professor Milan Bartos (Yugoslavia) also stated that "development of international law and codification might be distinguished in abstracto, but it would be impossible to say where codification ends and development begins." in 'Summary Record of the 6th Meeting' (20 May 1947) UN Doc A/AC.10/SR.6, 7 . 
The distinction between codification and progressive development, however artificial and untenable in practice, was politically useful to channel the consensus of the Committee. ${ }^{62}$ The distinction enabled both the scientific and the political approaches to find their expressions in the mandate of the future Commission, codification being scientific and progressive development political, and the work of the International Law Commission then should cover both aspects. The two terms "codification" and "progressive development" were then assigned clear-cut normative connotations in the final report of the Committee. ${ }^{63}$ As the Committee stated:

Some of the tasks might involve the drafting of a convention on a subject which has not yet been regulated by international law or in regard to which the law has not yet been highly developed or formulated in the practice of States. Other tasks might on the other hand involve the more precise formulation and systematization of the law in areas where there has been extensive State practice, precedent and doctrine. For convenience of reference, the Committee has referred to the first type of task as 'progressive development' and to the second type of task as 'codification' ...64

This formula was later incorporated into the statute of the International Law Commission. ${ }^{65}$

This dichotomy of codification/progressive development has a direct impact on the working methods and output of the International Law Commission, as embodied in its statute. For progressive development, the Commission

62 Dhokalia ( $\left.\mathrm{n}_{7}\right) 213$.

63 In the same report, however, the Committee acknowledged that the line of distinction was bound to be a blurred one. As the Committee stated: "For the codification of international law, the Committee recognized that no clear-cut distinction between the formulation of the law as it is and the law as it ought to be could be rigidly maintained in practice. It was pointed out that in any work of codification, the codifier inevitably has to fill in gaps in and amend the law in the light of new developments." 'Report of the Committee on the Progressive Development of International Law and its Codification on the Methods for Encouraging the Progressive Development of International Law and its Eventual Codification' (18 July 1947) UN Doc A/331, para 10.

64 Ibid para 7.

65 During the debate the sub-committee set up by the Sixth Committee, the formula was taken without reopening the issue. It met the expectations of both those favoured codification by conventions and those favoured codification by scientific restatement. See 'Report of the Sixth Committee Subcommittee 2' (18 November 1947) UN Doc A/C.6/ 193, 8-10. 
shall apply articles 16 and 17 of its statute, and the initiative is expected to come from the General Assembly, governments, intergovernmental organizations and others. In this case, a draft convention is the only appropriate form for the International Law Commission product. In contrast, the codification procedure applies in articles 18 to 24. Here, the Commission may, on its own motion, "survey the whole field of international law with a view to selecting topics for codification", subject to the approval of the topics by the General Assembly. This conceived difference of procedures did not prove to be sustainable, however. Very soon the Commission had to abandon the difference as a matter of practicality. ${ }^{66}$

By distinguishing yet including codification and progressive development in the mandate of the International Law Commission, the Commission was given a dual task, both as a codifier and a legislator. There were irreconcilable tensions between the two different roles and visions of the International Law Commission. Many of the confusions and difficulties faced by the Commission today could be understood in light of this structural division and the dichotomy inherent in its identity. The International Law Commission was a balanced project, i.e. it was designed to balance conservativism and progressivism. Its statute also reflects a compromise between political law-making and expert law-making, "a compromise between those who are in favour of government representatives and those who want personal experts to be charged with the task". 67

\section{4}

Dynamics of the International Law Commission

While the International Law Commission is entrusted with the dual tasks of codification and progressive development, its early work contained more elements of codification, than that of progressive development. ${ }^{68}$ Classic examples are the Commission's work on the law of the sea, diplomatic immunities, the law of treaties, and other topics in the 1950s and 1960s. ${ }^{69}$ The development

66 See United Nations, The Work of the International Law Commission, Volume I (8th edn, United Nations 2012) 47.

67 'Summary Record of the 3rd Meeting' (14 May 1947) UN Doc A/AC.10/SR.3, 5 .

68 A similar observation was made also by Vaughan Lowe, see United Nations, The International Law Commission Fifty Years after: An Evaluation - Proceedings of the Seminar Held to Commemorate the Fiftieth Anniversary of the International Law Commission (United Nations 2000) 172.

69 This led to the conclusion of the 1958 Convention on the Territorial Sea and the Contiguous Zone, the 1958 Convention on the High Seas, the 1958 Convention on Fishing and Conservation of the Living Resources of the High Seas, the $195^{8}$ Convention on the Continental Shelf, the 1961 Vienna Convention on Diplomatic Relations, the 1963 Vienna 
of law was exercised with caution and restraint, and often only in connection with clarification of established rules. The underlying idea was to transform unwritten rules of international law into international lex scriptum. Therefore, the International Law Commission had worked carefully not to embark on topics that did not contain any rules of customary or general international law, unless requested by the General Assembly for the purposes of preparing draft conventions. The 1969 Vienna Convention on the Law of Treaties was considered the International Law Commission's "last real success",70 by some. The validity of this judgment holds only if the work of the Commission was measured in terms of its ability to produce widely accepted conventions.

In the following decades, step by step, the International Law Commission started to engage with topics with law-making elements. Examples include law of treaties between States and international organizations or between international organizations, State succession, and non-navigational uses of international watercourses and international liability. An assessment done more than thirty years ago led to the conclusion that "the Commission at the present time is engaged primarily in progressive development, and the task of putting agreed customary practices and rules into treaty form is a small if not negligible part of that process".71

In recent years, the International Law Commission however engaged in the progressive development of international law more often and openly. The legislative elements of codification are more explicitly acknowledged by the Commission. ${ }^{72}$ The International Law Commission no longer considers itself barred from selecting a topic simply for the sparsity of established rules of

Convention on Consular Relations, and the 1969 Vienna Convention on the Law of Treaties.

70 Donald M McRae, 'The International Law Commission: Codification and Progressive Development after Forty Years' (1987) 25 ACDI 355, 357.

71 Ibid 362.

72 For example, the International Law Commission recognizes the rules on the responsibility of international organizations may be less established. As the commentary states: "It may occur that a provision in the articles on State responsibility could be regarded as representing codification, while the corresponding provision on the responsibility of international organizations is more in the nature of progressive development. In other words, the provisions of the present draft articles do not necessarily yet have the same authority as the corresponding provisions on State responsibility." ILC, 'Draft articles on the responsibility of international organizations' [2011] II(2) ILC Ybk 40. Another example is the principles on the allocation of loss in the case of transboundary harm arising out of hazardous activities: ILC [2006] II(2) ILC Ybk 59. Its commentaries set out that "the draft principles are therefore intended to contribute to the process of development of international law in this field". 
international law. ${ }^{73}$ Instead, the Commission seems to profess progressive development in a strategic way to steer the development of the law. ${ }^{74}$ By openly conceding the progressive nature of the work in question, the Commission is less bound by existing State practice and is capable of pushing further. This is what the Commission has done, for example, in its draft articles on the protection of persons in the event of disasters. The draft articles, "at the outset ... highlight the fact that the draft articles contain elements of both progressive development and codification of international law". ${ }^{75}$ In the case of draft guidelines on the protection of the atmosphere adopted on first reading in 2018, the International Law Commission highlights that it "seeks, through the progressive development of international law and its codification, to provide guidelines that may assist the international community as it addresses critical questions relating to transboundary and global protection of the atmosphere. ${ }^{76}$ These drafts are elaborated to prepare, equip or guide States in managing certain situations. Novel elements in those drafts are accepted precisely because it has been openly conceded that they constitute progressive development of international law.

One observes that on certain subjects the International Law Commission increasingly acts in the role of a legislator rather than a registrar. ${ }^{77}$ It can be said that " $[\mathrm{t}]$ he task is primarily of bringing the old principles upto date, of introducing the inevitable changes in the old rules, of reformulating them in

73 This is the case for the International Law Commission's draft articles on the expulsion of aliens. It is openly recognized by the International Law Commission in the commentaries that "the entire subject area does not have a foundation in customary international law or in the provisions of international conventions of a universal nature". "This is why the present draft articles involve both the codification and the progressive development of fundamental rules on the expulsion of aliens." See ILC, 'Draft articles on the expulsion of aliens' (2014) UN Doc A/69/10, 11.

74 The author once suggested certain constraints that might be placed on the work of the International Law Commission as a consequence of the dichotomy of codification and progressive development, see Chen Yifeng, 'Structural Limitations and Possible Future of the Work of the International Law Commission'(2010) 9 Chinese JIL 473.

75 ILC, 'Draft articles on the protection of persons in the event of disaster' (2016) UN Doc $\mathrm{A} / 71 / 10,13$.

76 ILC, 'Draft guidelines on protection of atmosphere' (2018) UN Doc A/73/10, 161.

77 For contrary opinions, see Pellet (n 26) 16; Hisashi Owada, 'International Law Commission and the Process of Law-formation' in United Nations, Making Better International Law: the International Law Commission at 50 - Proceedings of the United Nations Colloquium on Progressive Development and Codification of International Law(United Nations 1998) 171; also Michael Wood, 'The United Nations International Law Commission and Customary International Law' (Gaetano Morelli Lecture 4th edn: Rethinking The Doctrine Of Customary International Law, Rome, 27 May 2017). 
accordance with the new basic legal ideas, and of legislating in areas uncovered by traditional international law." ${ }^{\prime 7}$ The move from registrar to legislator is made possible by a constant oscillation between codification and progressive development. The strategic use of the interplay of codification and progressive development, rather than its opposition, has enabled to the International Law Commission to act proactively to advance the development of international law on certain important subjects.

\section{Products of the International Law Commission: Forms and Authority}

\section{Diversity of Forms}

In recent years, the International Law Commission has shown flexibility and diversity in the final forms for its output. ${ }^{79}$ The Commission produces not only draft conventions and draft articles, but also draft declarations, ${ }^{80}$ model rules, ${ }^{81}$ draft codes, ${ }^{82}$ draft statutes, ${ }^{83}$ guiding principles, ${ }^{84}$ draft principles,${ }^{85}$ conclusions,${ }^{86}$ draft conclusions, ${ }^{87}$ and guides to practice, ${ }^{88}$ and draft guidelines. ${ }^{89}$ It would seem that international conventions as the end result of the

78 See Subir Goswami, Politics in Law Making: A Study of the International Law Commission of the UN (Ashish Publishing House 1986) 59.

79 For a useful discussion, see Ramcharan (n 23) 73-78.

8 o ILC, 'Draft declaration on rights and duties of states' [1949] I ILC Ybk 287.

81 ILC, 'Model rules on arbitral procedure' [1958] II ILC Ybk 83.

82 ILC, 'Draft code of offences against the peace and security of mankind' [1954] II ILC Ybk 134; ILC, 'Draft code of crimes against the peace and security of mankind' [1996] II(2) ILC Ybk 17.

83 ILC, 'Draft statute for an international criminal court' [1994] II(2) ILC Ybk 26.

84 ILC, 'Guiding principles applicable to unilateral declarations of States capable of creating legal obligations' [2006] II(2) ILC Ybk 160; ILC, 'Principles of international law recognized in the Charter of the Nuremberg Tribunal and in the judgment of the Tribunal' [1950] II ILC Ybk 374 .

85 ILC, 'Draft principles on the allocation of loss in the case of transboundary harm arising out of hazardous activities' [2006] II(2) ILC Ybk 59.

86 ILC, 'Conclusions of the work of the Study Group on the fragmentation of international law: Difficulties arising from the diversification and expansion of international law' [2006] II (2) ILC Ybk 177 at para 251.

$87 \quad$ ILC, 'Draft conclusions on subsequent agreements and subsequent practice in relation to the interpretation of treaties' (2018) UN Doc A/73/10, 12; ILC, 'Draft conclusions on identification of customary international law' (2018) UN Doc A/73/10, 122.

88 ILC, 'Guide to practice on reservations to treaties' [2011] II(3) ILC Ybk 23.

89 ILC, 'Draft guidelines on the protection of the atmosphere' (2018) UN Doc A/73/10, 158. 
International Law Commission codification work have become an exception rather than the rule. During the past three decades, only three international conventions resulted from the work of the International Law Commission. ${ }^{90}$

Of course, international conventions remain a highly pertinent form of the Commission's output. Taking a recent example, in 2016 the International Law Commission recommended the General Assembly to elaborate a convention on the basis of the draft articles on the protection of persons in the event of disasters. The draft articles on crimes against humanity, whose first reading was completed in 2017, are also conceived in the form of a draft convention. During the debates of the Sixth Committee, proposals emerged for concluding an international convention on State responsibility based on the articles adopted by the International Law Commission in 2001. The argument made here is rather that the Commission no longer sees the elaboration of draft conventions as the only necessary form of its work.

The declining production of conventions is attributable to a number of factors. First of all, the making and ratification of treaties are politically costly because they require the involvement of various domestic political constituencies. In recent years, States are seen to have less appetite for treaty making. Some treaties received a strikingly low number of ratifications, a phenomenon that must be rather discouraging and disturbing to the International Law Commission and its members. Nowadays the Special Rapporteurs, the International Law Commission and the Sixth Committee of the General Assembly are all less enthusiastic in pursuing the conclusion of multilateral conventions. Secondly, some recent topics of the Commission are by nature not suitable for treaty making. A typical example could be the report of the study group on "Fragmentation of international law: difficulties arising from the diversification and expansion of international law". ${ }^{11}$ Thirdly, the final products of the International Law Commission are increasingly seen as possessing a certain autonomous normative quality. They are capable of generating a broad influence on their own over the international legal process, independent of formal acceptance by States. The Special Rapporteurs and the Commission seem increasingly willing to accept soft forms other than formal treaties as the

90 Convention on the Law of the Non-Navigational Uses of International Watercourses, adopted 21 May 1997, entered into force 17 August 2014, UNTS registration no 52106; Rome Statute of the International Criminal Court, adopted 17 July 1998, entered into force 1 July 2002, 2187 UNTS 38544; United Nations Convention on Jurisdictional Immunities of States and their Property, adopted on 2 December 2004, not yet in force, UN Doc A/59/ 508 .

ILC, [2006] II(2) ILC Ybk 175. 
second-best choice for the outcome of their work, when the chance of having an international convention seems slim.

This brings the issues of authority and legitimacy to the forefront. Some scholars consider the growing diversity of form as an encouraging phenomenon to propel the International Law Commission "a much more effective organ".92 Some others are more concerned with the legitimacy and usefulness of the Commission's products in forms other than conventions. ${ }^{93}$ Questions are asked such as whether these soft forms are at all desirable or appropriate, what the legal nature and legal impact of those documents would be, and whether the adoption by the General Assembly would add any normative force to the Commission's final products. In essence the new forms raise normative doubts in three aspects: first, the nature of the International Law Commission's unconventional output; second, constitutionality of the mandate and methodology of the Commission; and third, the proper role and function of the Commission in the international law-making process.

\section{$2 \quad$ Sources of Authority}

The authority of the work of the Commission increasingly comes from varying sources, which might have a profound transformative effect upon its work. The change in the form of the products of the ILC is no more than a natural projection of the evolving role of the International Law Commission in a dynamic international society.

The following four sources can be identified as the sources of the Commission's authority. The first rests upon the political authority vested on the Commission by States. This is what was originally conceived of the work of the International Law Commission. The International Law Commission was expected to seek the approval of States for its work products, for example through the conclusion of international conventions at diplomatic conferences. The Commission was further expected to be guided with a view to consider the acceptability of its work by States. The political authority from States can also often seen be from a procedural perspective. The participation of States in the debates of the Sixth Committee of the General Assembly and in their responses to questionnaires gives certain democratic procedural legitimacy to the work of the International Law Commission. Although the responses of the Special Rapporteurs to States' concerns are often selective, the procedure does flush out the elements of the work, which States would actively oppose.

\footnotetext{
$92 \quad$ McRae (n 70) 364.

93 For a detailed account on the forms and authority of work products of the International Commission, see Murphy (n 6) 29-40.
} 
Outside the treaty-making context, States also quote the Commission's products in daily diplomacy and in dispute settlement procedures. Moreover, the International Law Commission's articles are also quoted by national courts. The political authority gained by States' endorsement is the authority traditionally associated with the Commission's work. This reflects the Statecentered paradigm of international law. States remain central to the international law-making process.

The second source of authority flows from inter-institutional crossfertilization. One should not overlook the fact that the reference and application of the work of the Commission by other institutions, including the International Court of Justice, has contributed to another level of authority through cross-reference and recognition. Notwithstanding the fact that the products of the International Law Commission are contained in soft forms or remain draft conventions, they are nevertheless often referred to by the International Court of Justice, other international tribunals, regional courts, and various international organizations as authoritative statements of international law. This gives weight to the authoritativeness of the work of the International Law Commission. It has been said that " $\mathrm{t}]$ he court, for its part, has nevertheless not hesitated to invoke the work of the International Law Commission where it has seemed appropriate to do so, without concerning itself with the formal question of how that work might fall within Article 38 of the Statute of the International Court of Justice. ${ }^{94}$ The International Law Commission's articles on responsibility of States for internationally wrongful acts are a well-known example in this regard. The articles have been quoted by the International Court of Justice, the World Trade Organization Appellate Body, the European Court of Human Rights, International arbitral tribunals and others in a number of cases and relevant rules have been treated as demonstrative of customary international law. ${ }^{95}$

The third source of authority derives from the intrinsic quality of the rules elaborated by the International Law Commission. This particularly applies to the work of the Commission in the realm of secondary rules, such as those topics concerning jurisdiction, the sources of international law, and international responsibility. In case of secondary rules, the practical influence of a topic often arises from the nature of the subject matter being part of the necessary normative infrastructure of international law. This may be further assisted by the fact that in the international legal order, there exists no rival work of

\footnotetext{
94 Watts (n 8).

95 See UNGA, 'Report of the Secretary-General', UN Doc A/62/62, UN Doc A/65/76, UN Doc $\mathrm{A} / 68 / 72$ and $\mathrm{UN}$ Doc $\mathrm{A} / 7_{1} / 8$ o.
} 
comparable systemization and equivalent weight as that of the International Law Commission. All these factors combined have consolidated the authority of the work of the Commission in those fields where the express acceptance of States in the form of treaties is often considered redundant. ${ }^{96} \mathrm{On}$ the contrary, the soft form of an outcome, such as draft articles, draft guidelines, or draft conclusions, does not by itself prevent States, or international organizations, from invoking and applying it. It is recognized that under certain circumstances codification in the form of a soft law instrument may prove as effective as a treaty. ${ }^{97}$

The fourth source of authority comes from the International Law Commission itself. The Commission is composed of experts of recognized competence and represents as a whole "the main forms of civilization" and "the principal legal systems of the world". 98 The work of the International Law Commission embodies the laborious efforts of its members as collective wisdom, and is adopted, with rare exceptions, through consensus. The work is well recognized among the teachings of the most highly qualified publicists of various nations, and constitutes "a subsidiary means for the determination of rules of international law". ${ }^{99}$ Moreover, the Commission is increasingly seen by international society as endowed with an institutional authority of its own. This authority has been cultivated and accumulated on the basis of its outstanding performance during the past seven decades. ${ }^{100}$ Therefore, authority of the work of the Commission, legal or political, may derive from the very fact that the work is produced by the Commission.

This list of the sources of authority is not exhaustive. Yet, it is illustrative of the diversified, blended sources from which the products of the Commission are capable of drawing their authority. The significance of this development is that it may produce some subtle but profound transformative effect

96 Even if it takes the form of a treaty, States may not accede to it simply because the States consider that the treaty rules are customary in nature.

97 See for example, Tomuschat (n 2) 104.

98 Statute of the ILC, UNGA Res 174 (II) (21 November 1947) as amended by UNGA Res 485(V) (12 December 1950) article 8.

99 Huang Huikang, 'The work of the International Law Commission and the Shaping of International law: in Commemoration of the Fiftieth Anniversary of the Commission' in United Nations (n 77) 314 .

100 For an illustration of the achievements of the International Law Commission in a publication published more than twenty years ago, see 'Introduction: The Achievement of the International Law Commission' in United Nations, International Law on the Eve of the Twenty-First Century: Views from the International Law Commission (United Nations 1997) $1-18$. 
on the identity and the work of the Commission. The richness of the sources of authority further provides room for the Commission to act more autonomously in its codification work, more detached from the political influence of States, more engaged with other actors in a globalized world. In some cases, the International Law Commission has sought to address its work to other actors in the international community, not necessarily only to States. This is the case for the Commission's draft articles on the responsibility of international organizations.

This also partly explains why the products of the Commission have not been much hampered by their soft form. The authority of the Commission's products does not necessarily require the conclusion of an international convention by States. The expertise of the International Law Commission in matters of international law is highly regarded by international society as a whole, and this allows its work to stand on its own institutional reputation.

\section{The Future of the International Law Commission: towards Becoming an Autonomous Law-Maker}

At a time of global social change, the Commission is increasingly called upon to work creatively and progressively. The Commission often has to advance the law rather than simply record the law. The recent work of the International Law Commission has shown an evolving notion of codification through restatement of existing law towards codification through formulating and legislating new law. This can be seen from the fact that the International Law Commission increasingly resorts to its mandate to promote the progressive development of international law when taking up new work. The International Law Commission more and more plays the role of an autonomous law-maker. This part offers a theoretical account on the law-making role of the International Law Commission.

\section{The Institutional Nature of the International Law Commission}

The institutional nature of the International Law Commission is an important yet often overlooked issue. Yet if one is to reconceive the Commission as an autonomous law-maker, a primary issue to be asked from the outset is whether the Commission is constitutionally authorized to engage in the making of international law?

There are three possible ways to approach the Commission as an institution. The first one is from the perspective of international institutional law. The Commission is established by the General Assembly as a subsidiary body 
of the Assembly. The United Nations is neither a super-State nor a world government. ${ }^{101}$ If the General Assembly has only recommendatory power, the International Law Commission cannot have legislative power which its creator does not possess. ${ }^{102}$ It follows that the products of the Commission do not have binding force unless they are formally accepted by States through the ratification of treaties. In cases where the draft conventions do bind States as reflective of customary international law, the authority of the products emanates from the substance of the rules, rather than their form.

The second approach is from the perspective of international relations. Under this view, the Commission may be interpreted as an agent of States, collectively. According to some, the Commission "has been empirically demonstrated to serve as a tool of States rather than as an independent body". 103 The formation and operation of the Commission in essence falls back on the sovereign wills of States. The work of the Commission is to accomplish the tasks that are entrusted to it by States through the General Assembly, namely the codification and development of international law. It follows that not only is it important for the Commission to seek the opinions of States when selecting topics, it is also essential that "the task of codification must be approached with the view of its eventual adoption within the framework of positive international law". ${ }^{104}$ This interpretation of the nature of the Commission is a crude reduction of the multiple roles and great potentials of the Commission.

A third perspective is to conceive of the International Law Commission as a trustee for the advancement of the international rule of law. ${ }^{105}$ It is true that the establishment of the Commission is based on the resolution of the General Assembly, and it is equally true that the effective operation of the Commission is only possible through constant interactions with and support from States. However, once created, the Commission is governed by its own statute solely. It is formally independent from States. Its mandate of codification stems from a long human history of pursuing international lex scriptum and, ultimately, the international rule of law. In this sense, the International Law Commission

\footnotetext{
101 See Reparation for injuries suffered in the service of the United Nations (Advisory Opinion) [1949] ICJ Rep 174, 179 .

102 This is emphasized by Peter Tomka, 'Major Complexities Encountered in Contemporary International Law-making' in United Nations (n 77) 212.

103 Jeffrey S Morton, The International Law Commission of the United Nations (University of South Carolina Press 2000) 109 .

104 Lauterpacht (n 28) 35 .

105 For a useful construction of international courts and tribunals as trustees in relation to their creators, see Karen Alter, 'Agent or Trustee: International Courts in Their Political Context' (2008) 14 EurJIntlRel 33.
} 
is different from other political bodies established under the United Nations. It has a transcendental mandate. The International Law Commission is not a political body. Instead, "it is an organ sui generis". ${ }^{106}$ The International Law Commission is observed to have occupied "the de facto status of principal legal instrument of the United Nations". 107

The International Law Commission should be studied as "an organ in the universal process of codification and development of international law".108 As discussed below, the legislative role of the International Law Commission might receive social recognition in the constitutionalization process of international law. ${ }^{109}$ In turn, the constitutional role of the Commission as a curtailed legislator also deserves more theoretical consideration. ${ }^{110}$ This may provide a thin but sustainable justification to conceive the Commission as an autonomous law-maker.

\section{$2 \quad$ The Concept of International Law Reconsidered}

The transformation of the International Law Commission into an autonomous law-maker is also facilitated by the changing nature of international law. Traditional international law is a law that developed through adjudication. International law, by reference to article 38 of the Statute of the International Court of Justice, is tied to the philosophy and practical need of using law for adjudicating inter-State disputes. The formalism of international law is closely related to the need of settling disputes between States, which has also driven early efforts to codify international law. An international court, when asked to resolve a specific dispute, should be able to apply the rules of international law in order to determine the respective rights and obligations of the State parties.

More recently, however, such an adjudicative concept of law has met with some criticism. It is seen as an expression of parochial "judiciary-centrism". ${ }^{111}$

\footnotetext{
106 Lauterpacht $\left(\mathrm{n}_{32}\right) 37$.

107 See Goswami (n 78$)$ 199.

108 For a useful discussion of the different institutional role of the International Law Commission, see Ramcharan (n 23) 9-28.

109 For useful reflections on the idea of constitutionalization, see Jan Klabbers, Anne Peters, and Geir Ulfstein, The Constitutionalization of International Law (Ou P 2009).

110 Alain Pellet suggests that the work of the International Law Commission is valuable as "they are part of the 'constitutional law' of the international society": Pellet (n 26) 22.

111 See, for example, an insightful critique on the "judiciary-centrism" by Onuma Yasuaki, 'A Transcivilizational Perspective on International Law: Questioning Prevalent Cognitive Frameworks in the Emerging Multi-Polar and Multi-Civilizational World of the TwentyFirst Century' (2009) 342 RdC 77, 250-65.
} 
The adjudicative function is but one of the several functions that international law operates through. ${ }^{112}$ International law is a language of empowerment and legitimization for certain specific claims or actions. International law also has a communicative and normative power which conditions a specific understanding and offers possible solutions. Furthermore, international law provides a regulatory scheme for international administration and governance.

Outside the adjudicative setting, the normative threshold for a rule to be recognized as part of the corpus of international law is considerably more lenient than the rigour required by Article 38 of the Statute of the International Court of Justice. "It is thus evident", as one author writes, "that in most cases, forums where international law is referred to, invoked, discussed, applied, and realized or implemented are outside the International Court of Justice."113 A large number of rules used in those non-judicial contexts do not belong to the traditional edifice of international law. It is now necessary to reconstruct the notion and corpus of international law in light of other functionalities of international law.

The concept of international law deserves a systemic reflection which requires a separate treatment and cannot be dealt with here. Yet, it is useful to highlight a few points about the process of building a new concept of international law. First, it is a move beyond formalism. A broad notion of international law could encompass informal forms such as guidelines, best practices, resolutions, programmes, guiding principles and such like. ${ }^{114}$ Under the traditional paradigm, these are at best appreciated as soft law, practically relevant but short of legal normativity. The new concept of international law should deal with the abundance of normative materials with a more receptive attitude. ${ }^{115}$ Secondly, in connection to informality, the new concept of international law should also go beyond positivism and the State-centered paradigm. Not only are new global laws emerging outside the sovereign domain, ${ }^{116}$ but the increasing legislative role of international organizations and other global actors also

\footnotetext{
112 See ibid $195^{-199 .}$

113 Ibid 258.

114 For some useful accounts on soft law, see Christine Chinkin, 'The Challenges of Soft Law: Development and Change in International Law' (1989) 38 ICLQ 850; Alan E Boyle, 'Some Reflections on the Relationship of Treaties and Soft Law' (1999) 48 ICLQ 901.

115 For example, the idea of graded normativity is suggested by Prosper Weil, 'Toward Relative Normativity in International Law' (1983) 77 AJIL 413.

116 See Gunther Teubner, Constitutional Fragments: Societal Constitutionalism in the Globalization (OUP 2012); also Gunther Teubner (ed), Global Law without a State (Aldershot 1997).
} 
deserves full recognition. The work of the International Law Commission may fit well into this revised concept of international law.

\section{$3 \quad$ Types of Legislation}

Legislation may also be understood in different senses. Legislation in a narrow sense refers to a sovereign exercise of laying down rules for its subjects, and is performed through national parliaments in the modern day. This definition applies nicely to legislation in the domestic context: the making of law in accordance with a constitutional procedure. Legislation is thus an exclusive prerogative of the sovereign. In a broad sense, however, legislation could be understood as a normative exercise in the formulation of general rules, with the constitutional implications for distribution of wealth, power and justice in a given society. This concept of legislation measures law-making by looking into normative outcome and distributive consequence. In the international society where there is no global sovereign, the narrow definition of legislation finds no application. The best yet narrow analogy is to interpret the conclusion of international conventions as a joint exercise of sovereign powers. Instead, the broad definition of legislation may offer better insights into the law-making process at the international level.

Alongside this broad notion of legislation, I venture to suggest that the International Law Commission engages in the following four types of legislation: "legislation through conceptualization", "legislation through lex scriptum", "legislation through codification" and "legislation through convention". These different types of legislation may not be mutually exclusive. It is possible that the International Law Commission engages different types of legislative work in a single work. Yet the typology aims at allowing for ae nuanced examination of how and when the Commission has become a law-maker, and how autonomous from States the Commission is in different circumstances.

Firstly, the International Law Commission may perform a legislative function by formulating a certain conceptual and normative framework, or sanctioning a certain paradigmatic and epistemic framework. In the words of Kenneth Keith, "the Commission's work has played a structural role in the international legal process. It has strongly influenced the way in which we think about international law and has helped to establish the intellectual framework within which we address, solve and answer international legal problems."117 The construction of State responsibility in terms of the failure of performance of international obligations and the exclusion of damage from the defining

117 See 'Presentation by Sir Kenneth Keith' in United Nations (n 77) 120. 
elements is a noteworthy example. ${ }^{118}$ The same holds true for the introduction of the concept of jus cogens in the 1969 Vienna Convention on the Law of Treaties.

Secondly, the International Law Commission may engage in international legislation by producing international lex scriptum. One should not underestimate the normative pull of the work of the Commission. The articles and guidelines are systemized and clearly stated, with credible authorities and preparatory work. They are readily available, easy to consult and apply. It may be noted that " $\mathrm{t}] \mathrm{he}$ change of source from custom to treaty may seem to be purely formal and adjectival, but it has inevitable repercussions on the substance." 119 As a result of the deliberations and of the approval of the Commission, "they will be of considerable potency in shaping scientific opinion and the practice of Governments".120

Moreover, the value of the work products of the Commission could also be appreciated in light of the revised concept of international law. In addition to their valuable role as evidence of customary international law, the products of the Commission could also be invoked and applied by States and actors in diplomatic discourse and other non-judicial contexts. Its work could play the functions of persuasion, legitimation and communication. The very existence of a systemized text carefully elaborated by the International Law Commission, whether legally binding or not, carries with it an inherent force of normativity that cannot be lightly denied or bypassed.

Thirdly, the International Law Commission may legislate in the course of codification. ${ }^{121}$ The interpretation of codification as transformation of rules in formality (from unwritten into written rules) seems to be a profound misinterpretation or a simplistic reduction, as the presumed existence of agreement on unwritten rules is largely a convenient fiction. Often differences among States are latent or deliberately withheld. They only emerge because of codification efforts when States are forced to take or reveal their positions on concrete points. An essential role of the codifying body is to formulate agreeable rules and to conduce States to agree on the relevant rules. ${ }^{122}$

\footnotetext{
118 See Brigitte Stern, 'A Plea for "Reconstruction" of International Responsibility' in Maurizio Ragazzi (ed), International Responsibility Today: Essays in Memory of Oscar Schachter (Martinus Nijhoff Publishers 2005) 93-106.

119 Jennings (n 18) 305 .

$120 \quad$ ILC (n 31) 16.

121 Hisashi Owada, based on a different definition of international legislation, divides legislation into three categories, namely, codification, progressive development, and legislation de novo. See Owada (n 77) 167-70.

122 See James L Brierly, 'The Future of Codification' (1931) 12 BYIL 1, 2-4; Lauterpacht (n 32) 18-22.
} 
This has been confirmed by various accounts made by the members of the International Law Commission. In reflecting upon his personal experience as a member and a Special Rapporteur of the International Law Commission, Hersch Lauterpacht concluded that "unlike codification in other fields, codification of international law must be substantially legislative in nature". ${ }^{23}$ It is noticeable that even for a topic such as the well-worn law of treaties, disagreements, uncertainties, and gaps existed practically for almost every aspect of the law. It is natural for the International Law Commission to select, reject, extend, reshape or revise the rules of international law with a view to conducing States for eventual approval. Another more recent account was offered by the former member Donald McRae on the work of the International Law Commission on transboundary aquifers, the effects of armed conflict on treaties, the reservations to treaties, and the responsibility of international organizations. His detailed examination reveals that the final outcomes are fraught with choices or innovations made on purpose by the special rapporteurs and the International Law Commission. ${ }^{124}$

In other cases, the Commission may anchor the corpus of its work on established principles and rules of international law, and the legislative element is often presented in the form of an elaboration, extension or transposition of existing rules or general principles. This is the case for the International Law Commission conclusions on subsequent agreements and subsequent practice in relation to the interpretation of treaties where the conclusions draw heavily from the articles 31 and 32 of the 1969 Vienna Convention on the Law of Treaties. ${ }^{125}$ The same can be said about the International Law Commission draft articles on the protection of persons in the event of disaster where the reference to human rights and to the principles of humanity, neutrality, impartiality and non-discrimination have the same function. ${ }^{126}$

Fourthly, the International Law Commission may legislate by drafting conventions for States. This applies to, for example, the drafting of the Rome Statute of the International Criminal Court. The role of the Commission is more of an advisor, functionally equivalent to a parliamentary draftsperson in some national framework. In this case, the legislative role of the Commission is highly decentralized or removed from the locus of power. While the work of the International Law Commission is appreciated, the final say lies with States.

\footnotetext{
123 Lauterpacht (n 32) 29.

124 Donald McRae, 'The Work of the International Law Commission (2007-2011): Progress and Prospects' (2012) 106 AJIL 322, 324-331.

125 ILC, 'Draft conclusions on subsequent agreements and subsequent practice in relation to the interpretation of treaties' (2018) UN Doc A/73/10, 12.

126 ILC (n 75) 13.
} 


\section{$4 \quad$ Limits on the Legislative Role of the International Law Commission}

One also must concede that the legislative role of the Commission is subject to a number of important limitations. First of all, the International Law Commission cannot legislate against concerted State interests. It is important for the International Law Commission to proceed with the political support of the States. The comparative advantages of the Commission largely reside in its proven ability of conceptual elaboration of general international law and of generating general consensus of international society through its constructive interaction with States and others. Any legislative proposal that meets strong opposition from powerful States may not get through easily. As a matter of reality, the final product of the International Law Commission would need to take into account the legitimate concerns of States. Secondly, the legislative exercise by the Commission proceeds as expert deliberations, leaving little room for political bargains and compromises. ${ }^{127}$ Its work "is lawyers' law, not politicians' law."128 The scientific and political division of codification is valid subject to important qualifications, as only a limited degree of political difference could be absorbed and translated into matters of technicality. The International Law Commission itself is not a suitable organ for legislation on highly politicized subjects. The General Assembly has constantly relegated the more politicized topics away from the Commission so as to allow States to have more direct and closer political engagement with the Commission. This can be seen from the cases of drafting the Rome Statute of the International Criminal Court and of the 1982 United Nations Convention on the Law of Sea, as both projects were taken back to States after the Commission had worked substantively on the subjects. Thirdly, the actual legislative effect of the International Law Commission depends to a considerable extent on the acceptance of the users of the work product of the Commission. In other words, the normative effect of the work of the International Law Commission cannot be forced by the Commission itself, but rather comes from the actual application by other actors, be it a State or international organization, an international tribunal or a domestic court.

International law today is undergoing profound structural changes, as are the codification projects and thus the role of the International Law Commission.

\footnotetext{
127 See Gerhard Hafner, 'The International Law Commission and the Future Codification of International Law' (1995-1996) 2 ILSA JICL 671, 673-74.

128 Pellet (n 26) 16.
} 
The codification work of the Commission is inherently legislative in nature. The International Law Commission has increasingly resorted to progressive development as a tactic to develop new law, and to keep itself occupied and relevant. The Commission performs a dual role in the international lawmaking process - as a registrar and legislator. The International Law Commission is seen to be operating with a renewed institutional confidence as an autonomous law-maker. The growing diversity in the form of the its products reflects the move of the Commission towards the role of a more autonomous law-maker.

The legislative function of the International Law Commission could be appreciated in light of constitutionalization of international law, where the constitutional role of the Commission could possibly be construed as a trustee for the development of the international rule of law. The work of the Commission is also a proof of need for a renewed understanding of international law being beyond a body of adjudicative rules.

The International Law Commission may exercise legislative functions in different situations, with varying levels of legislative depth from case to case. The contribution of the Commission should no longer be measured solely in terms of its contribution to the drafting of international conventions, but should be assessed in light of its own merit. Whilst the Commission's legislative authority remains limited, subject to various institutional and functional constraints, it has become an indispensable building block of law-making in the international legal order. 